\title{
TECHNOLOGIC LEVEL AND THE EFFECT OF FACTOR ENDOWMENT ON ECONOMIC GROWTH AND EMPLOYMENT
}

\section{DOI: 10.17261/Pressacademia.2015414365}

\section{Yusuf Kurtoglu'}

${ }^{1}$ Treasury Department of Turkey. yusuf.kurtoglu@hazine.gov.tr

\section{Keywords}

Technologic level, factor endowment, skilled labor, unskilled labor, economic growth.

\section{ABSTRACT}

The differences in the major determining factors of the competitive conditions for the new and conventional technological based sectors bring about differentiate as much in quality of production factors as the difference in the factor endowment. The primary effect of this situation on production structure emerges as the innovations on technological level. New technological patterns on production process entail renewing the skill level of workforce compatible with the new technologies. As the high technology based sectors developed in the fallowing process, parallel to the created value added increases in the economies, achieving higher level of realized growth rates might possible. In this study, within the frame of law of diminishing returns hypothesis, free movement of factors together with the technological level differences in sectors and the effects on economic structure have evaluated. Then, within the scope of endogenous economic growth approach and Cobb-Douglas type production function the effect of factor structure' changes on economic growth have examined.
JEL Classification

040, 041

\section{TEKNOLOJIK DÜZEY VE FAKTÖR DONANIMININ EKONOMIK BÜYÜME VE} ISTIHDAMA ETKISI

\section{Anahtar Kelimeler \\ ÖZET}

Teknolojik düzey,

faktör donanımı

Yeni ve gelenekselleşmiş teknolojilere dayanan sektörlerdeki rekabet koşullarının temel belirleyicilerinin farklı oluşu, faktör donanımının yoğunluğundaki farklılaşma vasıflı işgücü, vasıfsız işgücü, ekonomik büyüme. kadar, faktörlerin niteliklerinde de farklılaşmayı beraberinde getirmektedir. Bunun üretim yapısı üzerindeki öncelikli etkisi, teknoloji seviyesindeki yenilikler olarak kendisini göstermektedir. Üretimde yeni teknolojik yapılar ise, işgücü vasıfılık düzeyinde "yeni teknolojilerle uyumlu değişimi" zorunlu kılmaktadır. İzleyen süreçte ileri teknolojiye dayanan sektörler geliştikçe, ekonomilerde yaratılan katma değer artışına paralel olarak, daha yüksek düzeyde gerçekleşen ekonomik büyüme oranları mümkün olmaktadır. Bu çalışmada; öncelikle, azalan verimler kanunu varsayımından hareketle, faktörlerin serbest dolaşımı ile sektörlerdeki teknolojik düzey farklılığı ve bunun ekonomik yapıya etkileri üzerinde durulmuştur. Faktör

JEL Sınıflandırması 040,041 yapısındaki değişimin ekonomik büyüme üzerindeki etkisi ise içsel ekonomik büyüme modelleri yaklaşımıyla Cobb-Douglas tipi üretim fonksiyonu çerçevesinde incelenmektedir. 


\section{GíRiş}

Dünya ölçeğinde sermaye hareketleri ve ticareti düzenleyen kuralların giderek artan biçimde serbest uygulamalara dönük yenilikler içermesi, rekabetin uluslararası alanda hızla yaygınlaşmasına neden olduğu gibi, kar marjlarının daralmasına da yol açarak rekabet koşullarını güçleştirmektedir. Piyasalarda rekabetin artışı, firma faaliyetlerinin sürdürülmesinde faktör maliyetlerinin azaltılarak, faktörlerin birim kazancı ve verimlilik artışını zorunlu kılmaktadır. Toplam faktör verimliliğinin artırılması ise üretim sürecinde faktör donanımlarında ileri teknolojiye dayanan sermaye yoğun ve bu teknolojik yapıyla uyumlu vasıflı işgücünün bir arada bulunmasını gerektirmektedir.

Gelişmiş teknolojiye dayanan sektörlerdeki rekabet koşulları, piyasaya ilk çıkan yeni ürünün satışından elde edilecek kazancın yüksekliği nedeniyle, ürün yeniliğinin önemini ön plana çıkarmaktadır. Bu ise teknolojilerin devamlı ve hızlı bir şekilde yenilenmesi zorunluluğunu doğurmaktadır. Bunun yanında, standartlaşmış teknolojilerle büyük hacimde üretim yapılan sektörler de varlığını devam ettirmektedir. Bu sektörlerde rekabet edilebilirliğin temel koşulu, bu teknolojilere uygun vasıfıııktaki işgücü için ödenen düşük işgücü maliyetleri yanında, mevcut ürünlerin kalitesinde iyileşme ve tasarım değişiklileriyle markalaşma yoluna gidilmesi şeklinde belirginleşmektedir.

Yeni ve gelenekselleşmiş teknolojilere dayanan sektörlerdeki rekabet koşullarının temel belirleyicilerinin farklı oluşu, faktör donanımının yoğunluğundaki farklılaşma kadar, faktörlerin niteliklerinde de farklılaşmayı beraberinde getirmektedir. Çalışmamızda; öncelikle, azalan verimler kanunu varsayımından hareketle, faktörlerin serbest dolaşımı ile sektörlerdeki teknolojik düzey farklılı̆̆ı ve bunun ekonomik yapıya etkileri üzerinde durulmuştur. Bu çerçevede, ekonomideki faktör donanımı ve faktör yoğunluklarına ilişkin farklılıkların büyüme ve istihdam açısından değerlendirmesi yapılmaktadır.

Çalışma kapsamı şunlardır. İkinci kısımda, faktörlerin serbest dolaşımı ve teknolojik düzey farklılığının etkileri incelenmektedir. Üçüncü kısımda, faktör yapısındaki değişimin toplam faktör verimliliği, ekonomik büyüme ve istihdama olan etkileri ele alınmıştır. Dördüncü kısımda, ekonomik büyüme, içsel ekonomik büyüme modelleri yaklaşımıyla ve CobbDouglas tipi üretim fonksiyonu çerçevesinde incelenmektedir. Bu değerlendirmelerin sonucunda oluşan görüşler ise, çalışmanın son kısmında yer almaktadır.

\section{TEKNOLOJiK DÜZEYE GÖRE SEKTÖRLER VE EKONOMIK YAPI}

\subsection{Azalan Verimler Kanunu ve Sermayenin Marjinal Getirisi}

Azalan Verimler Kanunu yaklaşımında; i. üretim faktörleri hareketli değildir ve ekonomik faaliyetler mevcut faktör bileşenleriyle yapılmaktadır ve ii. teknolojinin gelişmişlik düzeyi ile işgücünün vasıflııı düzeyi bakımından bir ayırım bulunmamaktadır.

Bu koşullarda; Sermaye(K) faktörünün bol olduğu gelişmiş ülkelerde sermayenin en son biriminin (marjinal) kazancı $\left(\mathrm{MPP}_{\mathrm{K}}\right)$, sermaye faktörünün görece az olduğu ülkelere göre daha düşüktür. (Belirli bir ölçek büyüklüğünde iken; $K$ arttıkça, $M P_{K}$ azalacaktır.) Sermayenin görece bol olduğu gelişmiş ülkelerde ölçek ekonomisinin gerektirdiği yoğunlukta sermaye faktörü kullanıldığından, tam istihdam seviyesine yaklaştıkça her birim ilave sermayenin kazancı azalacaktır. Gelişmekte olan ülkelerde ise sermaye faktörü 
açığı olduğundan ilave sermaye kazancı birim işgücü başına üretimi artıracağından, toplam üretim artacak ve $\mathrm{MPP}_{\mathbf{K}}$ artış gösterecektir. Bu nedenle,

$\mathrm{MPP}_{\mathrm{K}}{ }^{\mathrm{GOÜ}}>\mathrm{MPP}_{\mathrm{K}}{ }^{\mathrm{GÜ}}$

olur.

GOÜ Gelişmekte Olan Ülkeler, GÜ Gelişmiş Ülkeler, MPP Marjinal Fiziki Getiri, K Sermaye faktörü, $L$ isşgücü faktörü, $M P P_{K}$ Sermayenin Marjinal Fiziki Getirisi, MPP Marjinal Fiziki Getirisi.

\subsection{Faktörlerin Serbest Dolaşımı ile Teknolojik Düzey Farklılığının Etkileri}

Sermaye ve işgücü faktörlerinin dolaşımındaki serbestlik sonucu üretim faktörleri, faktörlerin görece kıt olup, kazancın en yüksek olduğu bölgelere yönelir. Dolaşımdaki serbestliğe paralel olarak, sermaye/işgücü oranı ve faktör fiyatları hızla eşitlenmeye doğru gider. (Lucas, 2002:33) Bu yaklaşıma göre, yatırımların karlıı̆ı bakımından coğrafi farklılık ile gelişmiş ülke, gelişmekte olan ülke ayırımı belirli ölçülerde ortadan kalkmaktadır. Bu süreçte belirginleşen en önemli gelişme, teknoloji seviyesinin yenilenme düzeyi, bunun hızındaki artış ve yeni teknoloji ile uyumlu insan gücü varlığının vasıflııı düzeyindeki değişim ve gelişim olacaktır. Çünkü, insan kaynakları sermayesinin vasıflıık düzeyi, ülkelerin genel anlamda gelişmişlik düzeyleri ile kişi başı gelir ve eğitim düzeyi, rekabetçi piyasa koşullarının varlığı ve etkin işleyişi gibi birçok unsur tarafından belirlenmektedir.

Tam rekabetçi mal ve işgücü piyasalarında çalışanların gelirleri, üretimdeki paylarının piyasa koşullarında belirlenen marjinal değerine eşit olacaktır. İnsan gücü faktörü tarafından yaratılan üretimin değeri, öncelikle kendisine yapılan yatırımla ilgilidir. Bunun yanında, işgücü piyasalarının işleyişinin rekabet koşullarına uyum sağlayacak yapıda olması, bu faktörün etkin kullanımı ve yaratacağı değer açısından büyük önem taşır.

Murphy ve Salehi (2003) çalışmasında; insan gücü varlığının vasıflılık düzeyi, onun sahip olduğu bilgi ve yaratıcılık vasıflarının toplamından oluşmaktadır. Buna göre, sadece okul eğitimiyle elde edilen bilgiye dayanan vasıflılık sahibi olmak, insan gücü varlı̆ı̆ın ekonomik büyüme sürecine katılımı sırasında gerekli etkiyi yapmaktan uzak kalmaktadır. Çünkü, toplam vasıflılı̆ı̆ı sadece bilgi birikiminden oluşan kısmı üretim sürecinde kullanılacak, yaratıcılık vasfının kullanımıyla elde edilecek katkıdan faydalanılamayacaktır. Bu nedenle, işgücü piyasasındaki çalışma koşulları ve özellikle ücretin belirlenmesine ilişkin politika ve düzenlemelerin, insan sermayesinin yaratıcılığını ön planda tutarak, üretim sürecinde çalışanların verimliliğini artıııcı teşvikler içermesi önem taşır.

O halde, ekonomik büyüme sürecinde, sahip olunan teknolojinin gelişmişlik düzeyi kadar, insan gücü sermayesinin vasıflıık düzeyinin, onun eğitim ve yaratıcılığını artıracak şekilde geliştirilmesi de etken olacaktır. Yani, işgücünün vasıflıık düzeyinin, durağan bir olgu olarak değil, ancak dinamik ve gelişime açık bir süreçte gerekli etkiyi göstereceği ortaya çıkmaktadır. Çalışmamızda tanımlanan vasıflı işgücünün, bu niteliklere sahip olduğu varsayılmaktadır. Üretim teknolojisinin yenilik düzeyindeki farklılıklar, işgücünün vasıflıık düzeyinin kullanılan teknolojinin gelişmişlik seviyesiyle uyumunu gerekli kılmaktadır. Yeni teknolojiler, daha yüksek mesleki ve teorik eğitim ile iş deneyimi ve vasıflılık gerektirirken, standartlaşmış teknolojilerle üretim daha az vasıflı işgücüyle yapılabilmektedir. Iş̧ücünün 
artan vasıfılık düzeyinin, sermaye/işgücü oranının görece daha yüksek olduğu ileri teknoloji ile üretim sürecinde bir araya gelmesi, üretim faaliyetleri sonucunda daha yüksek katma değer yaratılmasını sağlayacaktır. Böylelikle, ileri teknolojiye dayalı üretim yapan sektörlerde, gerek sermaye gerek işgücü faktörünün birim verimliliği, işgücü yoğun ve standartlaşmış teknolojiye dayanan sektörlerdeki sermaye ve işgücü faktör verimliliklerinin üzerinde olacaktır. Buna ilişkin süreç şöyle özetlenebilir.

AT ve LT sektörlerindeki faktör donanımı koşullarından kaynaklanan ve aşağıdaki (2-10) denklemlerde gösterilen, $\mathrm{MR}=\mathrm{MC}$ (marjinal gelir, marjinal maliyet eşitliği) oluşumundaki farklılık nedeniyle;

$(\mathrm{W} / \mathrm{KD})^{\mathrm{AT}}>(\mathrm{W} / \mathrm{KD})^{\mathrm{LT}}$

olmaktadır.

Bu da gelişmiş teknoloji kullanımının bir göstergesi niteliğindedir.

Tanımlar; W toplam ücret tutarı, KD yaratılan katma değer, AT gelişmiş teknolojiye dayanan, fiziki ve vasıflı insan sermayesi yoğun sektörler (ör.uzay-havacılık, kimya, tıbbioptik, bilişim), LT vasıfsız işgücü yoğun (ör.mobilya, konfeksiyon) ve orta düzey fiziki sermaye yoğun (ör.tekstil, demir-çelik, deri) standart teknolojiye dayanan sektörler.(Nahuis, 2003:277-278)

Denklem (2)'ye göre;

$L_{v}{ }^{A T}>L_{v}{ }^{L T}$

sonucu çıkar.

$L_{\mathbf{v}}$, birim işgücü verimi.

Denklem (2)'deki AT tanımına uygun olarak, K/L oranının AT'de yüksek oluşu nedeniyle;

$\mathrm{L}^{\mathrm{AT}} /$ tot $_{\mathrm{L}}<\mathrm{L}^{\mathrm{LT}} /$ tot $_{\mathrm{L}}$

'dir.

$\mathrm{L}^{\mathrm{AT}}$ ileri teknoloji sektörlerindeki istihdam düzeyi, $\mathrm{L}^{\mathrm{LT}}$ düşük teknolojiye dayanan

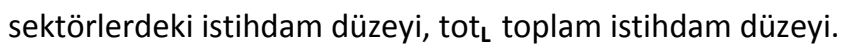

İleri teknolojiye dayalı üretim yapan sektörlerde, sermaye ve vasıflı işgücü faktörlerinin marjinal getirilerinin görece yüksekliği nedeniyle;

$\left(M P P_{K}+M P P_{L}\right)^{A T}>\left(M P P_{K}+M P P_{L}\right)^{L T}$

olur.

Bu durum, özellikle Goü’ler için daha belirgin olarak ortaya çıkacaktır.

Çünkü; (5) nolu denklemin açılımına göre; AT sektöründe çalışan vasıflı işgücünün ücreti, iki sektördeki işgücü verimindeki farklılığı yansıtacak ve

$\mathrm{MPP}_{\mathrm{L}}{ }^{A T}=\mathrm{L}_{\mathbf{v}}{ }^{\mathrm{AT}}-\mathrm{L}_{\mathbf{v}}{ }^{\mathrm{LT}}=M C^{A T}$ 
olacaktır.

$L_{v}{ }^{A T}$ gelişmiş teknolojiye dayanan sektörlerde birim işgücü verimi, $L_{v}{ }^{L T}$ işgücü yoğunstandart teknolojiye dayanan sektörlerde birim işgücü verimi, $M C^{\mathrm{AT}}$ AT sektöründeki marjinal maliyet.

LT sektöründe, işgücü ücretleri için böyle bir verim farkından söz edilemeyeceğinden;

$\mathrm{MPP}_{\mathrm{L}}^{\mathrm{LT}}=\mathrm{W}=\mathrm{MC}^{\mathrm{LT}}$

olmaktadır.

Iki sektördeki işgücü marjinal getiri farkıılığı,

$$
=\mathrm{L}_{\mathrm{va}}{ }^{\mathrm{AT}}>\mathrm{L}_{\mathrm{va}}{ }^{\mathrm{LT}}
$$

olduğunu göstermektedir.

$L_{v a}{ }^{A T}, A T^{\prime}$ de işgücü ortalama vasıflılık düzeyi, $L_{v a}{ }^{L T}, L T^{\prime}$ de işgücünün ortalama vasıflılık düzeyi.

Denklemler (2-8)'deki tanımlamalara göre, sektörler arasında fiyat farklılı̆̆ı oluşmakta ve

$\mathrm{P}_{\mathrm{AT}}>\mathrm{P}_{\mathrm{LT}}$ olmaktadır.

$P$, piyasa satış fiyatı

İki sektör arasında fiyat düzeyindeki bu fark; AT sektöründe $M C=M R=P$ eşitliği, LT sektörüyle karşılaştırıldığında, patent, lisans, teknik bilgi (know how) kazanç farklarını vermektedir.

Yukarıda, AT sektöründeki sermaye faktörü yoğunluğuna dayanan işgücü faktörünün verimlilik farkı ile açıklanan $M R=M C$ eşitliğinin oluşumu, literatürde değişik tanımlamalarla anlatılmaktadır. Peretto(2003:331)'da, firmanın AT sektöründeki ar-ge harcamasının üst sınırı; yeni ürün için yaptığı harcamanın alternatif maliyetine, yani, yeni ürünün marjinal maliyetine eşit olacaktır. Firmaların birim ar-ge harcamaları karşılı̆ında vergi iadesi aldıkları varsayılmakta ve kar, vergi sonrası marjinal kazanca eşit olmaktadır. Böylelikle, yeni üründen elde edilecek kazanç, sermaye piyasalarındaki arbitraj kazancından düşük olmayacaktır. Nahuis(2003:196) çalışmasında ise benzer bir yaklaşımla; ar-ge amaçı firmaya özel bilgi için yapılacak yatııım, bu yatııııı marjinal kazancının, bilgi edinimi için gereken sermaye maliyetine eşit olduğu noktaya kadar sürecektir. Buna göre, AT sektöründe üretken-verimli bilgiye (productive knowledge) yapılan yatııım harcaması nedeniyle, vasıflı işgücüne ödenen ücret, ar-ge yatırımının marjinal getirisine göre belirleneceğinden, $A T^{\prime}$ de $M C=M R=W$ olmaktadır.

Bu durumda AT sektöründeki MC, ar-ge'de istihdam edilen işgücüyle elde edilen yeni bilginin marjinal miktarının, bu bilginin piyasadaki fiyatına göre belirlenen değerini ifade edecektir. LT sektöründe de $M C$, üretim faaliyetinde kullanılan en son birim işgücü ve sermaye maliyetinden oluşmaktadır. 
Ürünlerin piyasa satış fiyatları, arza ilişkin maliyetler ile piyasada oluşan talep koşulları tarafından belirlenmektedir. Talebi etkileyen unsurların iki sektördeki nihai ürün satış fiyatlarına etkisi ise şöyle olacaktır:

a) LT sektöründeki ürünlere olan piyasa talebi, talebin gelir esnekliğinin düşüklüğü nedeniyle katıdır. Bu da LT sektöründe fiyatların ve buna bağlı olarak da ücretlerin görece düşük oluşunun temel iktisadi nedenini oluşturur.

b) Talebin, fiyat ve ikame esnekliğinin düşük, gelir esnekliğinin görece yüksek olduğu AT sektöründeki marjinal getiri ise LT sektöründeki marjinal getirinin üzerinde oluşmaktadır.

Nihai ürün arzını etkileyen unsurlar açısından bakıldığında, marjinal maliyetler iki sektörün maliyet yapılarındaki farklı koşulların sonucunu yansıtacaktır. Gerek firmanın kendisine ait ar-ge sürecinde, gerek ekonomideki mevcut bilgi stokunun yayılması sonucunda elde edilen yeni teknolojilerin firma ve sektördeki uygulamaları aşamasında, işgücü vasıflılık düzeyi ön plana çıkacaktır. Bu açıdan bakıldığında, denklem (8)'de ifade edildiği üzere, AT sektöründe istihdam edilen insan kaynaklarının vasıflılık düzeyi LT sektörüne göre daha yüksek olacaktır.

Buna göre; piyasa talebi ve mevcut gelir düzeyi tarafından belirlenen fiyat oluşumuna ilişkin yukarıda (a) ve (b)'de belirtilen koşullar ile arza ilişkin maliyetler/veya birim verimlilik kapsamında, yukarıdaki (2-8) denklemlerde tanımlandığı şekliyle, insan kaynaklarının vasıflılık düzeyindeki farklılıklar, işgücü faktörü için;

$K D^{A T}>K D^{L T}$

sonucunu doğurmaktadır.

Ekonomik faaliyetler geneli için,

AT/GSYIH > LT/GSYIH

koşullarının geçerli olması halinde;

GSYIH : Gayri safi yurtiçi hasıla veya ekonomide (AT/GSYiH) payı arttığında; bunun doğal sonucu olarak, ekonomik büyüme oranı üzerinde AT sektörünün payı LT sektörünün payından yüksek olacaktır.

\section{FAKTÖR YAPISINDAKI DEĞişiMIN ETKILERI}

\subsection{Faktör Yapısındaki Değişimin Toplam Faktör Verimliliği, İstihdam Düzeyi ve Ekonomik Büyümeye Etkisi}

Genel fiyat düzeyi artış oranının üzerindeki otonom ücret artışları, işgücünün marjinal maliyetini yükselterek, ülke içi üretim maliyetlerinde artış yoluyla rekabet gücü kaybına neden olacaktır. Bu durumda, diğer faktör maliyetleri veri iken, otonom ücret artışı öncesi dönemle karşılaştırıldığında;

$M C_{L}>M C_{K}$

olur. 
İ̧gücü maliyetlerindeki artışlar, rekabet koşullarına uyumu zorlaştıracağından; faktör yoğunluğu sermaye lehine artı̧̧ eğilimi gösterecek ve ekonomide normal koşulların geçerliliği varsayımı altında; yatırımlarda sermaye / işgücü (K/L) oranı artacaktır. Sermaye faktörü lehine değişen faktör yoğunluğu sonucunda; $\mathrm{MP}_{\mathrm{K}}$ ve $\mathrm{MP} \mathrm{P}_{\mathrm{L}}$ 'de artış olacaktır. $\mathrm{Bu}$ ise toplam faktör verimliğinde (TFV) artış anlamına gelecektir. Gelişmiş teknolojilerin yoğunluğu ve insan kaynakları vasıfılık düzeyinin yüksekliği nedeniyle, AT sektöründeki TFV artışı ise daha yüksek oranda olacaktır.

Buna karşın, yüksek ücret maliyetleri nedeniyle, işgücü faktörüne olan talep gerileyeceğinden; toplam istihdam düzeyi azalıp, işsizlik oranı artacak, ücret gelirlerinin ulusal gelir içindeki payı gerileyecek ve ekonomide talep açığı oluşacaktır.

$(\mathrm{W} / \text { GSYiH })_{\mathrm{t} 1}<(\mathrm{W} / \mathrm{GSYIH})_{\mathrm{t}-1}$

olur.

$\mathrm{t}$, zaman

Yatııım ve üretim faaliyetlerinde sermaye faktörü kullanımı yoğunluğundaki artışın ekonomik büyüme üzerinde kısa ve orta vadedeki etkileri ise şöyle olacaktır. Öncelikle, TFV artışının büyüme üzerinde katkısı olumlu yönde olurken, talep açığı nedeniyle bu etki negatif yönlü baskı oluşturur. Net etki ise bu iki etkinin büyüklüğü ve AT sektörünün GSYiH içerisindeki payına göre belirlenecektir.

Uzun vadede rekabetçi piyasa koşullarına uygun olarak işleyen bir ekonomik yapıda, büyüme oranını belirleyen temel etkenler; toplam arza ilişkin faktör maliyetleri ile toplam talebin gelir esnekliği ve talebi etkileyen diğer faktörler, uygulanan para ve maliye politikaları, ihracat mallarına olan dış talebin fiyat ve gelir esneklikleri olarak belirginleşmektedir.

\subsection{Faktör Donanımındaki Değişimin İstihdam Yapısına Etkisi}

Sermaye/işgücü oranındaki artış ve TFV artışı birlikte düşünüldüğünde; rekabet koşulları, ekonomide ileri teknolojiye dayanan sektörlerin GSYiH payının artırılmasını gerekli kılacaktır. AT sektörünün geliştirilmesi, yaratılan yüksek oranlı katma değer nedeniyle, ekonomik büyümenin devamlılı̆ı açısından gerekli bir koşul niteliği taşımaktadır. Bu durum, aynı zamanda, insan gücü kaynaklarının vasıflıık düzeyinde artış yönünde bir farklılaşmayı gerektirdiğinden, üretim faktörü olarak işgücünün istihdam yapısını da etkileyecektir. Buna göre, ürün piyasalarındaki arz koşullarında, AT sektörleri lehine bir artış olacağı varsayıldığında, işgücü talep yapısı değişecek ve bunun sonucunda;

$\mathrm{LD}_{\mathrm{va}}{ }^{\mathrm{AT}}>\mathrm{LD}_{\mathrm{va}}{ }^{\mathrm{LT}}$

olacaktır.

$L D_{\text {va }}$, vasıflı işgücü talebi

Buna göre; AT sektörleri için talep edilen işgücünün ortalama vasıflılık düzeyi, LT sektörleri için talep edilen işgücü ortalama vasıfılık düzeyinin üzerinde olacak demektir. 
Ancak, faktör talepleri piyasa koşullarına uygun olarak belirleneceğinden, AT ve LT sektörlerinde işgücü talebine temel oluşturacak ücret düzeyleri;

(5)no.lu denklem koşulları gereği,

$\mathrm{W}=\mathrm{MPL}_{\mathrm{va}}{ }^{\mathrm{AT}}$

$\mathrm{W}=\mathrm{MPL}_{\mathrm{va}}{ }^{\mathrm{LT}}$

eşitliklerine uygun olarak belirlenecektir.

Bu nedenle; toplam istihdam düzeyi, yukarıdaki eşitliklerde ifade edilen işgücünün marjinal verimliliğini belirleyen koşullar ile AT ve LT sektörlerinin GSMH paylarına ve bu paylardaki gelişime uygun olarak belirlenecektir. Bu sonuç, her iki sektör için de işgücü arzının ücret esnekliğinin birden büyük olduğu varsayıımına dayandırılmışır.

\section{FAKTÖR DONANIMI VE EKONOMIK BÜYÜME}

Bu kısımda ekonomik büyüme ile istihdamı etkileyen koşullar; AT ve LT sektörlerindeki faktör donanımının farklı oluşu varsayımıyla, Cobb-Douglas üretim fonksiyonu ile içsel ekonomik büyüme modelleri çerçevesinde incelenmektedir.

\subsection{Sektörel Bazda Farklı Faktör Donanımı ve Farklı Politika Gerekliliği}

Arza ilişkin koşulların yeterli ve uygun olduğu varsayımı altında, ekonomik büyüme, toplam talep koşulları tarafından belirlenecektir. Toplam talebi belirleyen kişi başı gerçek gelir düzeyi, zevk ve tercihler gibi temel unsurlar veri olarak alındığında; AT sektöründeki üretim artışının sürmesi, arza ilişkin diğer koşulların da yerine getirilmesini gerektirir. Bu koşulların başında; AT sektörü ar-ge yatırımları için temel üretim faktörü olan vasıflı işgücü arzı gelir.

Vasıfsız işgücü yoğun, görece standartlaşmış teknoloji ve/veya AT sektörüne göre daha düşük orandaki sermaye yoğunluğunu içeren LT sektörü için geçerli olan arz-talep koşulları, AT sektöründeki arz-talep dengesi ve üretim artışı için hangi ölçüde geçerli olacaktır. Bu temel yaklaşımdan hareketle, ekonomik büyüme sürecini etkileyen faktörlere bakııdığında; sektör bazında yaklaşım, birinci derecede ele alınması gereken önemli bir husus olarak karşımıza çıkmaktadır. Çünkü, iki farklı faktör donanımı ve ürün deseninin varlığı; bu sektörlerdeki arz ve talep dengesinin, farklı değişkenler tarafından belirlenmesi ve etkilenmesine neden olmaktadır.

Ekonomideki sektörlere ilişkin olarak AT ve LT sektörleri şeklinde bir ayırıma gidilmesiyle; iki sektörün maliyet yapıları, buna bağı̆ olarak da fiyat düzeyleri, istihdamın nitelik ve niceliği ile rekabet koşullarındaki farkıııkların ortaya konulması mümkün olacaktır. Örneğin, LT sektöründe rekabet gücünün artııııması; işgücü piyasası çalışma koşullarının esnek yapıda oluşu ve düşük ücret politikası uygulamaları yoluyla işgücü maliyetlerinin düşürülmesi veya sermaye yoğun ve ileri teknoloji içeren üretim yapısına dönüşümün sağlanması halinde mümkün olacaktır. AT sektöründe düşük ücret politikasının uygulanması halinde, bu durum vasıflı işgücü arzı üzerinde olumsuz yönde etki yapacağından, bu uygulama sektördeki rekabet gücü kazanımı açısından geçerli bir politika seçeneği oluşturmayacaktır. Ar-ge sürecindeki gereklilik nedeniyle, AT sektöründe 
vasıflı işgücü istihdamı zorunlu olacağından, izlenecek istihdam ve ücret politikalarının buna uygun olması gerekir.

Buna göre, ekonomik büyümeye ilişkin politika seçeneklerinin uygulanabilirliği; mevcut ekonomik gelişmişlik düzeyi ve varolan üretim faktörü donanımı yanında, izlenecek büyüme ve istihdam politikaları ile yakından ilgili olacaktır. Bu nedenle, belirlenen öncelikli ekonomi politikası hedeflerine paralel olarak; belirli bir oranda sağlanmış olan ekonomik büyümeye rağmen, işsizlik oranında artış görülebilecek veya işsizliğin azalmasına rağmen, daha düşük oranlı bir ekonomik büyüme oranı ile karşılaşılması mümkün olacaktır.

\subsection{Kuram ve Bulgular}

İ̧gücü yoğun sanayilerle karşılaştıııldığında, ileri teknolojiye dayalı sanayilerde ar-ge yatıımlarının daha yüksek oranlarda yapılmasının temel nedenleri olarak; bu sektörlerdeki, başta vasıfı işgücü imkanları olmak üzere, ar-ge için gerekli bilgi stoku, fiziki teçhizat, organizasyon, finansman olanakları ile ölçek ekonomisinin varlığı ve uygulama yetenekleri belirtilebilir.

Ar-ge yatırımlarının yoğun olduğu sektörlerde yaratılan katma değer, vasıflı insan sermayesi varlığının toplam faktör verimliliğine olumlu katkısı nedeniyle, daha yüksek düzeyde gerçekleşecektir. Bu yaklaşım paralelinde; ileri teknolojiye dayanan sanayilerin toplam imalat sanayi sektöründe görece yüksek paya sahip olduğu gelişmiş ülkelerde, vasıflı işgücünün yaratılan toplam katma değer içerisindeki payı daha yüksek olacaktır. Nitekim, Peneder'in $(2001: 123,127)$ araştırmasında, 1997 yılı itibariyle ülkeler bazındaki imalat sanayi toplam katma değerinin işgücü tarafından yaratılan kısmının vasıflıık bazındaki dağııımına göre; vasıflı işgücünün payı, Amerika Birleşik Devletleri(ABD), İlanda, Hollanda, İsveç ve Norveç gibi gelişmiş ülkelerde, \% 51,8 ile \% 65,5 arasında bulunmuştur. Katma değerin toplam üretim faktörleri bazındaki dağılımına göre ise teknoloji payı en yüksek olan iki ülke, \% 37,7 ile İrlanda ve \% 29,8 ile ABD'yi, İsveç, Fransa ve Almanya sırasıyla \% 28,6, $\% 27,7$ ve $\% 26,1^{\prime}$ lik paylarla izlemektedir.

Vasıflı işgücüne yapılan yatııımların bir üst sınııının olduğu belirtilen Nahuis çalışmasında (2003:128,305) ise teknoloji, iç ve dış ar-ge toplamlarından oluşan insan gücü sermayesinin bir fonksiyonu olarak ele alınmaktadır. Teknoloji, toplam üretim değerinin girdiler düşüldükten sonra kalan kısmı veya üretimin, girdi miktarındaki değişiklikle açıklanamayan kısmından oluşmaktadır. Yazara göre (a.g.e.:21, 214, 232), ar-ge yatıııının kazancını ifade eden 'yaratılan net katma değerdeki artıştan' söz edilebilmesi için; bu değerin, sermayenin alternatif kazancı olan faizin üzerinde bulunması gerekir. Çünkü, vasıflı işgücü, üretim sürecindeki katkısı nedeniyle, büyüme açısından yeni yatırım gibi bir işlev görmekte ve firmaya özel bilgi sermayesi üreterek sermaye stokunu artırmaktadır. Vasıflı işgücüne yapılan yatııım, ödenen ücret tutarı, alternatif kazancı oluşturan faiz getirisini aştı̆ı̆ı noktada, insan sermayesi için azalan kazanç söz konusu olacaktır. Bu noktadan itibaren ilave edilecek her birim vasıfı işgücü istihdamının ücret maliyetindeki artış nedeniyle, şirketin ar-ge faaliyetlerinden elde edeceği kazanç, faiz getirisi karşısında gerileyecektir. Bu nedenle, ar-ge harcamaları ve bu amaçla istihdam edilecek vasıflı işgücü istihdamı durdurulacaktır. Çünkü bu noktadan sonraki yatırım giderleri, ar-ge sonucunda elde edilecek kazancın üzerinde oluşacak ve şirket zarar edecektir. 
Mohnen (2002:52-53) çalışmasında da Nahuis yaklaşımına paralellik görülmekte ve sermaye ile işgücü faktörleri getirilerinin bu faktörlerin marjinal maliyetlerine eşitleneceği varsayımı altında, ekonomik büyüme otonom teknolojik değişiklikle açıklanmaktadır. Teknolojik değişiklik ise firma ar-ge'si ve bilgi yayılmasına dayanan toplam faktör verimliliğindeki artışı ifade etmektedir.

1960-1990 döneminde 93 ülkede insan sermayesi ile büyüme arasındaki ilişkinin araştırıldığı Bils ve Klenow incelemesinde $(2000: 1165,1170,1171)$, eğitim, insan sermayesi ve teknoloji/verimlilik artışı ilişkisi üzerinde durulmaktadır. Araştırmaya göre, okullaşma düzeyindeki bir yıllık artış, yıllık büyüme oranında \% 0,21'lik artışa neden olmaktadır. Büyüme oranındaki artış, \% 80 oranında, teknolojideki daha hızlı olan artışa dayandırılmaktadır. Çünkü, insan sermayesindeki büyüme yeni teknolojilerin uygulanmasını kolaylaştırmaktadır.

Büyüme teorisi yaklaşımında, eğitimin başlangıç düzeyi ekonomik büyüme üzerinde doğrusal yönde bir etkiye sahiptir. Ancak, Krueger ve Lindahl (2001:1128-1130) tarafından 110 ülke için yapılan araştırmada ise bu şekilde doğrusal bir ilişkinin her düzeydeki başlangıç eğitimi için geçerli olmadığı, etkileşimin farklılık gösterdiği tespit edilmiştir. Başlangıç eğitim düzeyi düşük olan ülkelerde eğitimin büyüme üzerindeki etkisi pozitif yönde olurken, orta düzey eğitim grubundaki ülkelerde belirgin bir ilişki görülmemiş, başlangıç eğitim seviyesi yüksek düzeyde artış gösteren ülkelerdeki ilişki ise ters yönlü olarak bulunmuştur.

İ̧̧ücü dağılımı ve ücretlerin eğitim düzeyine göre farklılaştırıldığı, ücretlerin marjinal kazanca eşitliği varsayımına dayalı olan büyüme teorisi yaklaşımına göre, eğitim seviyesindeki bir artış işgücü verimliği ve ekonomik büyümede artışa neden olacaktır. Bu konudaki bazı deneysel çalışmalara Gonand'ın $(2007: 7,8)$ makalesinde yer verilmiştir. Örneğin, ABD'de 1948 ve 1979 yılları arasındaki dönemi kapsayan Jorgenson'un araştırmasında, verimlilikteki artışın yaklaşık beşte birinin, işgücü girdisi kalitesindeki artıştan kaynaklandığı belirlenmiştir. Bassanini ve Scarpetta'nın 21 OECD ülkesi için 19711998 dönemini kapsayan ve insan sermayesi göstergesi olarak ortalama okullaşma yılının alındığı büyüme regresyonuna göre; eğitim süresindeki bir yıllık artış, uzun dönemde kişi başına üretim düzeyini yaklaşık \% 6 oranında artırmaktadır.

Ülkeler bazında işgücü başına üretim miktarı ve kişi başı gelir farklılıklarının incelendiği Hall ve Jones çalışmasında (1999) ise ülke bazındaki farklılıklar, ağılıklı olarak kurumsallaşma ve hükümet politikaları gibi sosyal altyapı oluşumlarına dayandırılmaktadır. Buna göre, işgücü başına düşen üretimdeki farklılıkların ancak bir kısmı fiziki sermaye ve insan sermayesindeki farklılıklarla açıklanabilecektir. Ülkeler bazında, temelde, sosyal altyapının benzer yapılara sahip olmayışının, fiziki sermaye birikimi ve eğitim olanakları ile verimlilik üzerindeki etkileri, farklı gelir düzeyleri ve ekonomik büyüme oranlarına neden olmaktadır.

\subsection{Model}

Çalışmamızda, oluşturulan büyüme modeli kapsamında ileri teknolojiye dayanan (AT) ve geleneksel sektörler (LT) olmak üzere, ekonomik faaliyetlerde iki sektörün varlığı esas alınmıştır. Bu kapsamda, Cobb Douglas tipi üretim fonksiyonu ve içsel büyüme 
modellerinden yola çıkılarak bir büyüme modeli oluşturulmuş ve modelde vasıflı işgücü ile ekonomik büyüme ilişkisi incelenmiştir.

Sektörlere ilişkin temel varsayımlar:

AT sektöründe;

- Illeri teknolojiye dayanan ve vasıflı işgücü yoğun üretim yapılmaktadır.

- Şirkete özel ar-ge harcamaları veya yeni teknolojilerin uygulanması sürecinde gerekli olan insan kaynakları yatırımlarının finansmanı için mali koşullar yeterlidir.

- Eşitlik (2)'deki AT ve LT tanımlarına uygun olarak, K/L oranının AT sektörlerde yüksek oluşu nedeniyle; $\mathrm{MPP}_{\mathrm{K}, \mathrm{L}}^{\mathrm{AT}}>\mathrm{MPP}_{\mathrm{K}, \mathrm{L}}^{\mathrm{LT}}$ olmaktadır.

- Tekelci rekabet koşulları geçerlidir.

- Büyük ölçek ve buna paralel olarak sabit maliyetlerin yüksekliği söz konusu olmaktadır.

LT sektöründe;

- Tam rekabetçi piyasa koşulları geçerlidir.

- Vasıfsız işgücü maliyeti, vasıflı işgücü maliyetinden düşüktür.

- Ekonomide işsizlik bulunduğundan üretim faktörü temini açısından işgücü arzı bir kısıt oluşturmamaktadır.

Cobb Douglas üretim fonksiyonu temel varsayımları:

- İşgücü vasıfııık düzeyinde farklılık bulunmuyor, işgücü, tek tip vasıfııık düzeyindeki bir faktör olarak alınıyor.

- Teknoloji, K/L oranı şeklinde ve tek tip gelişmişlik düzeyinde belirginleşiyor.

- $\quad$ sermaye ve işgücü faktörlerinin bire bir ikamesi söz konusu. Bir faktörün marjinal kazancı artarken, diğerinin kazancı aynı oranda azalmaktadır.

- Faktörler (K ve L) girdi oranı kadar çıktı oranına sahiptir.

Model çerçevesinde hazırlanan ilk denklemimiz aşağıdaki gibidir.

$Y=A+k+L n_{K}+e_{t}$

$Y$ işgücü başına gerçek GSYiH, A toplam faktör verimliliği, $k$ sermaye oranı katsayısı, Ln işgücü oranı katsayısı, $\mathrm{K}$ işgücü başına sermaye stoku, e hata payı, $\mathrm{t}$ zaman dilimi.

Model varsayımı gereği; sermaye oranı katsayısının büyük oluşu, K/L oranının yüksekliğini ve üretimde yoğun olarak sermaye faktörü kullanımını ifade ederken, işgücü oranı katsayısının daha büyük olması ise sektörün işgücü yoğun üretim yaptığı anlamına gelmektedir.

Cobb Douglas tipi üretim fonksiyonuna, içsel ekonomik büyüme modelleri yaklaşımıyla, arge'de istihdam edilen vasıflı işgücü tarafından yaratılan katma değeri yazdığımızda; 
Üretim fonksiyonu;

$L v_{Y}=A+L v_{B S}+e_{t}$

şeklinde ifade edilecektir.

$L v_{Y}$, ar-ge'de istihdam edilen vasıflı işgücü başına reel gelir

A, mevcut teknolojik düzey, üretim bilgi stoku

Lv, ar-ge'de istihdam edilen vasıflı işgücü oranı katsayısı

BS, vasıflı işgücü başına ar-ge'de kullanılan bilgi sermayesi (firmaya özel + firma dışından elde edilen bilgi),

(17) ve (18) no.lu denklemlerin birleştirilmesiyle, AT ve LT sektörleri için üretim fonksiyonu;

$Y=A+k+h+L n_{K}+L V_{B S}+e_{t}$

olmaktadır.

$Y$ ar-ge süreci dahil üretimde istihdam edilen vasıflı ve vasıfsız işgücü başına gerçek gelir, $h$ üretim için istihdam edilen vasıflı işgücü oranı katsayısı, Ln üretim için istihdam edilen vasıfsız işgücü oranı katsayısı.

Cobb-Douglas fonksiyonuna (19) nolu denklemde yapılan ek, içsel ekonomik büyüme modellerinde sözü edilen insan gücü ve üretim bilgisi sermayesinin büyüme sürecine yaptığı katkıyı ifade etmektedir. Bu katkı, ar-ge sürecinde çalışan vasıfı insan sermayesinin doğrudan yarattığı katma değer ve gerçekleştirilen yeniliğin diğer üretim faktörlerinin verimliliğinde sağladığı artışa ilişkin değerlerin toplamından oluşmaktadır. Bu sonuç, Cobb-Douglas varsayımına uygun olup; ar-ge sürecinin içselleşmesiyle elde edilen toplam katma değer artışını, firmanın üretim artışını, ifade eder. Ancak, bu durum, CobbDouglas'ın diğer ilkesi ile örtüşmez. Vasıfı işgücü faktörünün artan katkısı, vasıfsız işgücü ve sermaye faktörlerinin katkısını azaltmamaktadır. Vasıfı işgücünün bu katkısı içsel büyüme modelleri yaklaşımının karakteristik özelliğini ifade eder.

\section{SONUÇ VE DEĞERLENDIRME}

Toplam talebin yeterli olduğu varsayıldığında; ekonomik büyüme oranı, toplam arz koşulları ve sahip olunan faktör yoğunlukları tarafından belirlenecektir. Rekabetçi piyasa koşulları, ekonomik büyüme sürecinde, ileri teknolojiye dayalı üretimin geliştirilmesi yoluyla faktör verimliliklerinin artırımasını zorunlu kılmaktadır. Çalışmamızda incelenen model varsayımlarına göre, insan kaynakları varlığının vasıfılık düzeyi, yaratılan katma değer ve toplam faktör verimliliğini doğrudan etkileyen en önemli faktör konumundadır. Vasıflı işgücünün verimlilik düzeyine etkisi; gerek firmaya özel ar-ge çalışmaları ve ileri teknolojileri "yaparak öğrenme" yöntemiyle, gerek mevcut bilgi stokunun patent, lisans satışları vb. yollarla ekonomik yaşamda kullanılmasıyla yayıgınlaşmakta ve artmaktadır. Bu nedenle, vasıflı işgücü faktörü arzının yeterli büyüklükte olması, ekonomik faaliyetlerde rekabet üstünlüğü sağlama açısından gerekli görülmektedir. 
Vasıflı işgücü istihdamına dayanan ar-ge faaliyetlerinin sektörler bazında yaygınlaştırılması ekonomik büyüme ve rekabet gücünün artırılmasına olumlu yönde katkı yapmakla birlikte, ar-ge'ye dayanan sektörlerdeki gelişimin toplam istihdam üzerindeki etkisi sınırlıdır. Ekonomik istikrar bakımından, büyüme ve istihdam artışının birlikte sağlanması önem taşıdığından; izlenecek ekonomi politikalarında ar-ge'ye dayanan sektörler ve işgücü yoğun sektörlerin birarada gelişimine olanak sağlayacak önceliklere yer verilmesi gerekmektedir. Bu çerçevede, dış rekabete açık bir ekonomide işgücü yoğun sektörlerde üretim ve istihdam artışı elde edilmesinde; ölçek ekonomilerinin varlığı yanında, toplam arza ilişkin maliyet unsurlarının dünya ile rekabeti mümkün kılacak düzeyde bulunması önem taşır.

İleri teknolojiye dayalı sektörlerin gelişimdeki temel unsur, vasıflı insan gücü varlığıdır. Ancak, insan sermayesinin ar-ge sürecindeki katkısı veya teknolojik yayılma nedeniyle elde edilen yeni bilginin azalan verime tabi oluşu, ileri teknolojiye dayanan sektörlerin gelişimini sınırılandırır. İleri teknoloji sektörüne dayanan ekonomik büyümenin sürmesi, yeni ürün geliştirilmesi ve onun gerisindeki insan gücü varlığının ürettiği bilginin azalan veya sabit getiri yerine, artan getiriye sahip olması, insan varlığının nitelik ve nicelik olarak gelişiminin devamlılığını gerektirir.

İleri teknoloji ve işgücü yoğun sektörlerin her ikisinde de toplam arza ilişkin koşulların rekabet açısından yeterli ve uygun olduğu varsayımı altında, ekonomik büyümenin temel belirleyicileri; satın alma gücünü ifade eden kişi başı harcanabilir gelir düzeyi, toplam talep koşulları ve pazar hacminin büyüklüğü oluşturur. Yüksek satın alma gücüyle desteklenen gelişmiş ülke ekonomilerinde büyümenin sürükleyici motor gücünü, doğal olarak, ağırlıklı oranda talebin gelir esnekliğinin yüksek olduğu ileri teknolojiye dayanan sektörler oluşturmaktadır.

Gelişmekte olan ülkelerdeki ekonomik büyümenin sürükleyici gücünü, faktör donanımı ve kişi başı gelir düzeyine uygun olarak, büyük ölçüde işgücü yoğun ve daha düşük oranda sermaye yoğun sektörlere dönük talep oluşturur. Ancak, bu ülkelerdeki işgücünün vasıfıılık düzeyi ve sektörlerin teknolojik gelişmişlik düzeyi görece düşük olduğundan; yaratılan katma değer ve faktör gelirleri açısından bakıldığında, işgücü yoğun sektörlerin ekonomide toplam talep artışına katkısı sınırlı kalmaktadr. Buna göre, rekabet gücü kazanımı ve büyüme sürecindeki olumlu katkısı nedeniyle; gelişmekte olan ekonomilerde, işgücü faktörünün vasıfılık düzeyinin artırılmasına dönük politikalara öncelik verilmesi gereği, önemli bir koşul olarak ortaya çıkmaktadır.

\section{KAYNAKÇA}

Aghion, P., Howitt, P. (1999), "Endogenous Growth Theory," The MIT Press, Cambridge, Massachusetts London, England, Third Printing.

Ahn, Sanghoon, (2002), “Competition, Innovation and Productivity Growth: A Review of Theory and Evidence," OECD Economics Department Working Paper No.317, 17.

Barro, R.J. and Sala-i-Martin, X. (1999), “Economic Growth, The MIT Press Cambridge,” Massachusetts London.

Bassanini, A. And Scarpetta, S. (2001), “Does Human Capital Matter for Growth in OECD Countries? Evidence from Pooled Mean-Group Estimates," OECD Economic Department Working Papers No.282. 
Bayoumi, T. And Haacker M. (2002), "It's Not What You Make, It's How You Use It: Measuring the Welfare Benefits of the IT Revolution Across Countries," IMF Working Paper-Research Department.

Bils, M ve Klenow, P.J. (2000), “Does Schooling Cause Growth?”, The American Economic Review, V.9, No.5, 1160-1183.

Blöndal, S., Field S. and Girouard, N.(2002), "Investment in Human Capital Through Post- Compulsory Education and Training: Selected Efficiency and Equity Aspects," OECD Economics Department Working Paper No.33.

Gonand, F.(2007), "The Impact on Growth of Higher Efficiency of Public Spending on Schools", OECD Economics Department Working Paper No.547.

Haacker, M. ve Morsink, J.(2002), "You Say You Want A Revolution: Information Technology and Growth," IMF Working Paper.

Hall, R.E. ve C.I. Jones (1999), "Why Do Some Countries Produce So much More Output Per Worker Than Others?", The Quarterly Journal of Economics, 114(1), 83-116.

Krueger, A.B. ve Lindahl, M.(2001), “Education for Growth: Why and For Whom?”, Journal of Economic Literature, Vol.39, pp.1101-1136.

Lucas, Jr.R.E.)2002), “Lectures on Economic Growth, Harvard University Press," Cambridge, Massachusetts, and London.

Mamgain, V.(2000), "Productivity Growth in Developing Countries-The Role of Efficiency, (in) Industrial Productivity," (der) (Edit.: Bruchey, S.), Garland Publishing, Inc. New York \& London.

Mohnen, P.(2002), "International R\&D Spillovers and Economic Growth, Edit.: Matti Pohjola, 'Information Technology, Productivity, and Economic Growth, International Evidence and Implications for Economic Development" (der) Oxford University Press, New York.

Murphy, Jr., R.D. and Salehi-Isfahani, D.(2003), "Labor Market Flexibility and Investment in Human Capital," Department of Economics, Virginia Tech, Blacksburg, VA. USA.

Nahuis, R.(2003), "Knowledge, Inequality and Growth in the New Economy," Edward Elgar Publishing Ltd., Cheltenham, UK, Northampton, MA. USA.

Peretto, P.F.(2003), "Fiscal Policy and Long-run Growth in R\&D-based Models with Endogenous Market Structure," Journal of Economic Growth, 8, 325-347.

Pohjola, M.(2002), "Information Technology and Economic Growth: Introduction and Conclusions," "Information Technology, Productivity, and Economic Growth, International Evidence and Implications for Economic Development"(der), (Edit.: Matti Pohjola), Oxford University Press, New York.

Quah, D.(2002), "The Weightless Economy in Economic Development," “Information Technology, Productivity, and Economic Growth, International Evidence and Implications for Economic Development"(der) (Edit.: Matti Pohjola), Oxford University Press, New York.

Peneder, Michael (2001), “Entrepreneurial Competition and Industrial Location”, Edward Elgar Publishing Ltd., UK, USA.

Rebelo, S.(2002), "The Role of Knowledge and Capital in Economic Growth," “Information Technology, Productivity, and Economic Growth, International Evidence and Implications for Economic Development"(der) (Edit.: Matti Pohjola), Oxford University Press, New York.

Verspagen, B.(2001), "Economic Growth and Technological Change: An Evolutionary Interpretation", STIDirectorate for Science, Technology and Industry-Working Papers 2001/1. 